\title{
USE OF THE VIRTUAL TEACHING CAMPUS IN THE COMPETENCIES OF UNIVERSITY TEACHERS
}

\author{
Ana Barrera \\ National University José Faustino Sánchez Carrión UNJFSG, Lima, (Perú). \\ E-mail: abarrera@unjfsc.edu.pe ORCID: https://orcid.org/0000-0001-8296-6519 \\ Francisco Hilario \\ Universidad Cesar Vallejo UCV, Lima, (Perú). \\ National University Federico Villarreal UNFV, Lima, (Perú). \\ E-mail: fhilariof@ucvvirtual.edu.pe ORCID: https://orcid.org/0000-0003-3153-9343 \\ Giro Rodriguez \\ Universidad Nacional Mayor de San Marcos UNMSM, Lima, (Perú). \\ Universidad Nacional Federico Villarreal UNFV, Lima, (Perú). \\ E-mail: crodriguezro@unmsm.edu.pe ORCID: https://orcid.org/0000-0003-2112-1349 \\ Jorge Figueroa \\ University San Martin de Porres USMP, Lima, (Perú). \\ E-mail: jfigueroar@usmp.pe ORCID: https://orcid.org/0000-0003-0884-2571
}

Recepción: 25/07/2021 Aceptación: 13/09/2021 Publicación: 29/09/2021

\section{Citación sugerida:}

Barrera, A., Hilario, F., Rodriguez, C., y Figueroa, J. (2021). Use of the virtual teaching campus in the competencies of university teachers. 3C TIC. Cuadernos de desarrollo aplicados a las TIC, 10(3), 103-119. https://doi. org/10.17993/3ctic.2021.103.103-119 


\section{ABSTRACT}

The present research study aims to determine the virtual teaching campus's effect on the competencies of teachers of the Faculty of Industrial Engineering, Systems and Computer Science of the Universidad Nacional José Faustino Sánchez Carrión - 2017. In addition, the research is applied, deductive method, quasi-experimental design of longitudinal cut and explanatory level. It was determined for the variable Virtual Teaching Campus dimensions such as technological infrastructure, quality of content, and web system, and the variable competencies of teachers the dimensions ICT and social competencies and methodological strategies. In every university, they are vital to improving the quality of teaching. On the other hand, an observation guide was applied as an instrument, validated by expert judgment reaching $91.4 \%$ and with acceptable reliability obtained through Cronbach's Alpha of 0.981. The population comprises 65 teachers of the Faculty of Industrial Engineering, Systems and Computer Science; we used a census sample because the population was small. Furthermore, the Student's T statistical method was applied. The results obtained show, with $95 \%$ confidence, that there is a high positive significant influence $(p=0.000$ and $a=0.05)$ produced by the use of the Virtual Teaching Campus on the competencies of the teachers of the Faculty of Industrial Engineering, Systems and Computer Science of the Universidad Nacional José Faustino Sánchez Carrión - 2017.

\section{KEYWORDS}

Virtual teaching, Teaching competencies, Virtual platforms. 


\section{INTRODUCTION}

Information and communication technology ICT has become critical for the daily activities and the success of companies; according to Ramirez (2020), Granda (2019), and Alcívar (2019), explain at present it is a fundamental tool in any organization, so platforms have been developed to support virtual teaching in universities, teachers by making use of new platforms would improve their skills and tasks within them, which is why it is necessary to evaluate the effectiveness and success of virtual teaching in the competencies of teachers to know if it is helping to improve their skills. According to Castro (2019), in the face of the proliferation of virtual teaching spaces, teachers' lack of knowledge of new competencies that go beyond uploading certain notes to virtual fields has been detected. According to Gutiérrez-Hinestroza et al. (2019), university teachers must assume new competencies and attitudes that respond to new models and conceptions of teaching and learning in our current knowledge society. Finally, according to Picón (2019), the effective use of virtual teaching has become a primary issue; however, it has not yet been demonstrated that there are significant effects on teachers' competencies. Therefore, the objective of the present research was to determine the effect of the use of the virtual teaching Campus on teachers' competencies, taking as a case the teachers of the Faculty of Industrial Engineering, Systems and Computer Science of the Universidad Nacional José Faustino Sánchez Carrión - 2017. The population consisted of 65 teachers of the Faculty of Industrial Engineering, Systems and Computer Science of the Universidad Nacional José Faustino Sánchez Carrión, being the census sample.

\section{PROBLEM STATEMENT}

\subsection{DESCRIPTION OF THE PROBLEM}

However, despite the technological advances and their applications in the different areas of the daily and professional life of human beings, in our country, there is a lack of technological culture in society because not everyone makes use of these technological advances and even distrusts them. This also occurs in the university environment; it has been observed that most teachers reject technological changes, that they 
do not adapt quickly to new technological resources and applications. Some do not want to learn how to use these technological improvements implemented in the University. Although there has been training in virtual teaching directed to teachers of the Faculty of Industrial Engineering, Systems and Computer Science, few teachers have attended the training, and therefore make little use or have not been making use of the virtual teaching campus or other virtual platforms, which could be affecting their skills and performance, which would imply that they would have little knowledge of technological resources with which to enrich the class sessions and communicate with their students.

\subsection{BASIS OF THE PROBLEM}

Due to the increase of virtual teaching spaces, the Universidad Nacional José Faustino Sanchez Carrión has detected a lack of knowledge of new teaching staff competencies beyond uploading specific notes to virtual fields. During digital transformation, in the face of new models of teaching and learning Hernández et al. (2018), university teachers must assume new competencies. However, it has not yet been demonstrated that there are significant effects of the effective use of virtual teaching on the competencies of teachers, which is why it is convenient to carry out a study taking only the teachers of the Faculty of Industrial Engineering, Systems, and Computer Science since they are the ones who have been using the virtual teaching campus in more significant numbers.

\subsection{OBJECTIVE OF THE INVESTIGATION}

We propose to improve the current virtual teaching campus and measure the effect it has on the competencies of the teachers of the Faculty of Industrial Engineering, Systems and Computer Science of the Universidad Nacional José Faustino Sánchez Carrión, with which we propose to provide a teaching process that is of quality according to the current demands. The following are our specific objectives:

- To determine the effect of the use of the e-learning Campus on the ICT competencies of teachers. 
- To determine the effect of the use of the e-learning Campus on the social competencies of teachers.

- To determine the effect of the use of the e-learning Campus on teachers' methodological strategies.

\section{PRELIMINARY CONCEPTS}

\subsection{VIRTUAL TEACHING CAMPUS}

Flores (2005) considers that the teaching-learning model acquires a new status, a new role, based on the use of technological tools and resources, whose implementation is rapidly expanding in all sectors and, more frequently, in the teaching and research environment through technological platforms to support learning, known as e-Learning platforms or simply Virtual Teaching.

Vidal (2004) indicates that incorporating these e-Learning technological platforms is becoming a complement increasingly valued by teachers and students who see a good element to "upload" notes, reference articles, use cases, practices, etc.

\subsection{COMPETENCIES}

According to Perrenoud (2004), the professional competencies of university professors can be defined as the set of knowledge, skills, attitudes, and values necessary for quality teaching. That is, what teachers have to know and know how to address the problems that teaching poses to them satisfactorily. For Perrenoud (2004), some of the reasons for opting for a competency-based profile are as follows:

- It focuses on the development as Barcia et al. (2017) of subjects' capacities, favoring the formation of critical and reflective professionals, autonomous and responsible in their professional performance, with the capacity to propose pedagogical alternatives and participate in decisions concerning education, at the levels and in the areas where it is their responsibility to act. 
- It refers to the need for lifelong learning that seeks to deepen and develop new skills throughout life.

- It opens spaces for the interrelation of skills and knowledge, promoting integral personal and professional development.

- Because it is contextualized, it is flexible to adapt to social demands, the needs of students' integral development, permanent learning, and attention to cultural diversity and the conditions in which teaching is developed.

- It provides versatility to the teaching-learning process and, therefore, its greater capacity to adapt to today's pace of change.

\section{$\underline{\text { ICT Competencies }}$}

According to Lion (2012), teachers' ICT competencies refer to the specific use of knowledge, skills, and abilities related to developing elements and processes that allow the effective, efficient, and innovative use of technological tools and resources.

\section{$\underline{\text { Social competencies }}$}

For Bisquerra (2017), social competence is the ability to maintain good relationships with other people. This implies mastering basic social skills, capacity for effective communication, respect, prosocial attitudes, assertiveness, etc.

For Coronado (n.d.), social competencies are skills to interact with other people in a socially acceptable and valued way, which benefits both participants. They are skills that allow us to express and communicate inadequate affections, desires, opinions, and expectations, respecting our rights and others'. 


\section{METHOD}

In this research, the hypothetical deductive method was used to start from general aspects of the research to reach particular situations. For this purpose, the type of research is applied because it is oriented to current, concrete, and identifiable problems of the use of the virtual field in the Faculty of Industrial Engineering, Systems and Informatics of the Universidad Nacional José Faustino Sánchez Carrión to which the researcher is going to give current solutions. The level of research is explanatory because it is not only dedicated to the description of concepts, but it allows determining the effect of the independent variable on the dependent variable in this research, that is, determining the effect produced by the use of the virtual teaching Campus on the competencies of the teachers of the Faculty of Industrial Engineering, Systems and Computer Science of the Universidad Nacional José Faustino Sánchez Carrión. The present research is of quasi-experimental design; the sample was evaluated and analyzed in two groups: the control group and experimental group; with pretest and posttest, the researcher cannot fully control the variables of the present research. It is longitudinal because it is intended to know the state of the control group at different times. Finally, it is prospective because the data to be taken in the present investigation are current data.

On the other hand, the target population is made up of 65 appointed professors of the Faculty of Industrial Engineering, Systems and Computer Science of the Universidad Nacional José Faustino Sánchez Carrión, which is detailed below:

Table 1. Population.

Source: FIISI Department Head.

\begin{tabular}{|r|c|c|}
\hline N. & Category & Teachers \\
\hline 1 & Principal & 17 \\
\hline 2 & Associates & 39 \\
\hline 3 & Assistants & 9 \\
\hline 4 & Practice Managers & 0 \\
\hline & Total Population & 65 \\
\hline
\end{tabular}




\section{RESULTS}

The implementation of the experiment was authorized and coordinated by the Dean of the Faculty of Industrial Engineering, Systems and Computer Science of the Universidad Nacional José Faustino Sanchez Carrión. The present research had a control group of 33 teachers and an experimental group of 32 teachers. A pretest was carried out where the instrument was applied to both groups, and data were collected before treatment, confirming the existing problems. In order to make improvements, we first identified the critical success factors in which we had to make improvements, as shown in Figure.

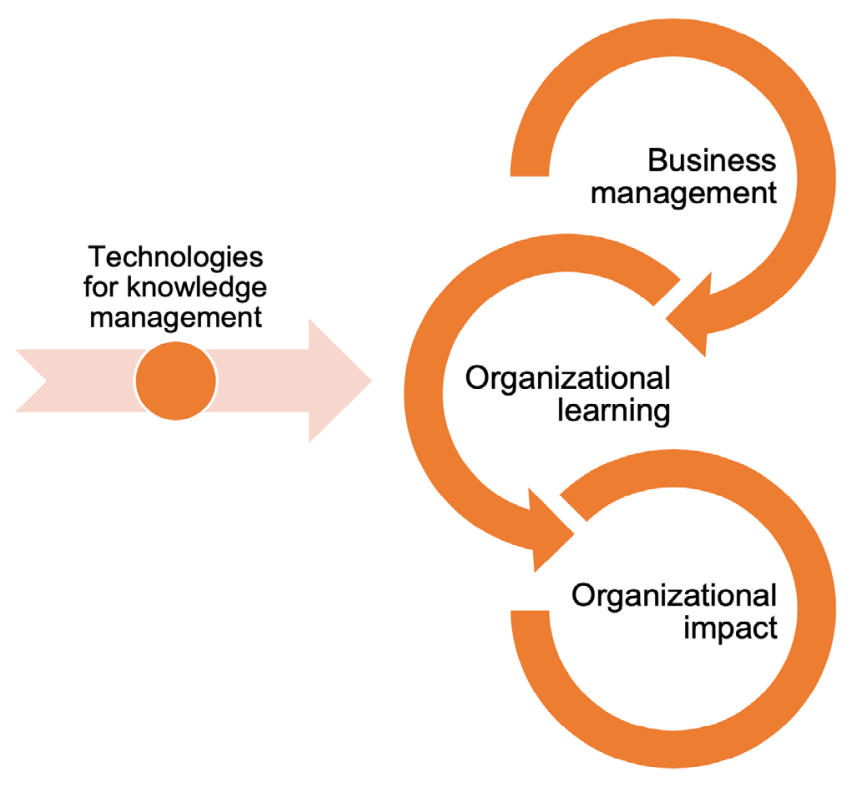

Figure 1. Critical success factors.

Source: own elaboration.

The improvements we implemented in each critical success factor are shown in Figure 2. 


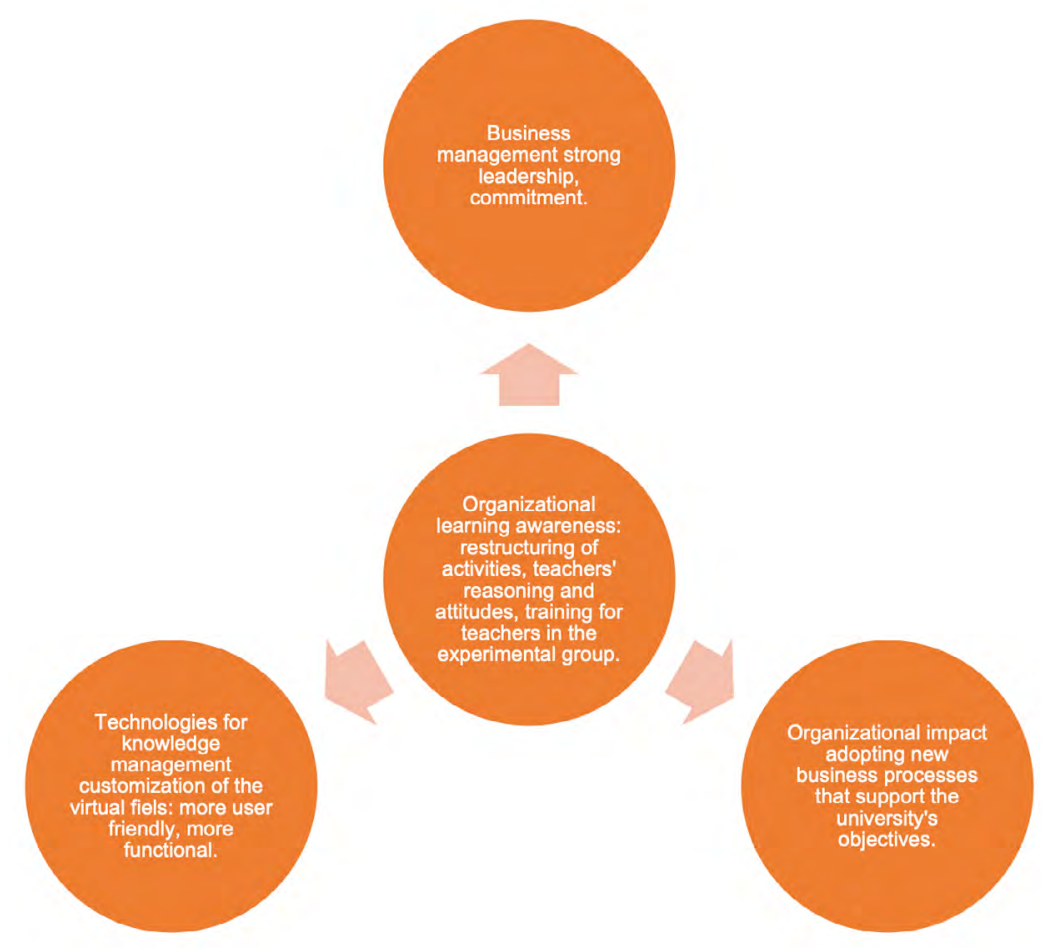

Figure 2. Improvements implemented in the Critical Success Factors.

Source: own elaboration.

As there were already complaints from teachers about the difficulty of accessing the virtual field, its management, and operation, it was also found that not all teachers had mastered the information technologies, and only some have adapted to its use, so we proceeded to make improvements to the virtual field and make it more friendly and functional.

After making improvements to the virtual field, the teachers belonging to the experimental group were trained and made aware of the use and importance of using the virtual field, not only for licensing and accreditation issues but also for their professional updating, indicating that the tools they were using are no longer the most effective Ramírez (2020), besides we it is facing new generations of students who 
demand new skills and we have to be prepared in the use of new technologies in university teaching as Picón (2020).

Several training sessions were held, after which the instrument, an observation guide with 31 items, was reapplied to obtain the post-test data. Data processing was carried out with SPSS software version 24.

For each item of the observation guide, frequency tables were used, which are statistical tools as Molinero and Chávez (2019), where the data are placed in columns representing the different values collected in the sample the frequencies (times) in which they occur.

The absolute frequency was found, which is the number of times a certain value appears in a statistical study. The sum of the absolute frequencies equals the total number of data, which is represented by $n$.

We also found the percentage and the cumulative percentage, which represents the percentages of all values less than or equal to the value considered. Bar charts, also known as column diagrams, are used for continuous or discrete variables and allow representing the frequency at each level of the variables of interest.

It is made up of rectangular bars arranged in parallel, they should have an equal width at their base, and the height of each bar is proportional to the frequency or number of elements belonging to the particular category.

To test the hypotheses, the Student's t-statistic method was applied. With the sample, it was possible to calculate a quantity that allows summarizing the result of the experiment in an objective way.

This quantity is the p-value that corresponds to the smallest possible significance level that can be chosen, for which the alternative hypothesis would be accepted, the p-value is a probability value that ranges between 0 and 1 , the null hypothesis is rejected if the p-value associated with the observed result is equal to or less than the established significance level, conventionally 0.05 or 0.01 . 
For the general hypothesis, we obtained the following results:

Table 2. Comparison of the before and after of the variable Teachers' Competencies applying the Student's T method.

\begin{tabular}{|c|c|c|c|c|}
\hline \multicolumn{1}{|c|}{ Median } & Variance & Standard Deviation & Interquartile Range \\
\hline Before & 80,44 & 435,028 & 20,857 & 35 \\
\hline After & 107,59 & 362,894 & 19,050 & 35 \\
\hline
\end{tabular}

Source: own elaboration.

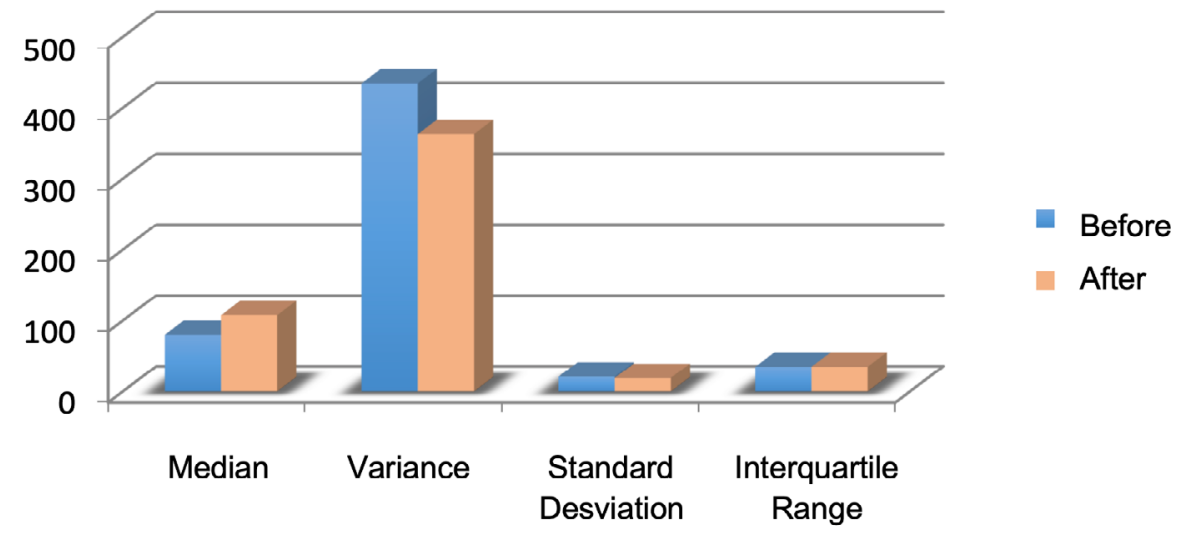

Figure 3. Comparison of the before and after of the variable Teachers' Competencies applying the Student's T method.

Source: own elaboration.

For the specific hypotheses, we obtained the following results:

Table 3. Comparison of the before and after of the ICT Competencies dimension applying Student's T method.

\begin{tabular}{|c|c|c|c|c|}
\hline \multicolumn{1}{c|}{} & Median & Variance & Standard Deviation & Interquartile Range \\
\hline Before & 25,75 & 85,355 & 9,239 & 14 \\
\hline After & 38,19 & 73,319 & 8,563 & 15 \\
\hline
\end{tabular}

Source: own elaboration. 


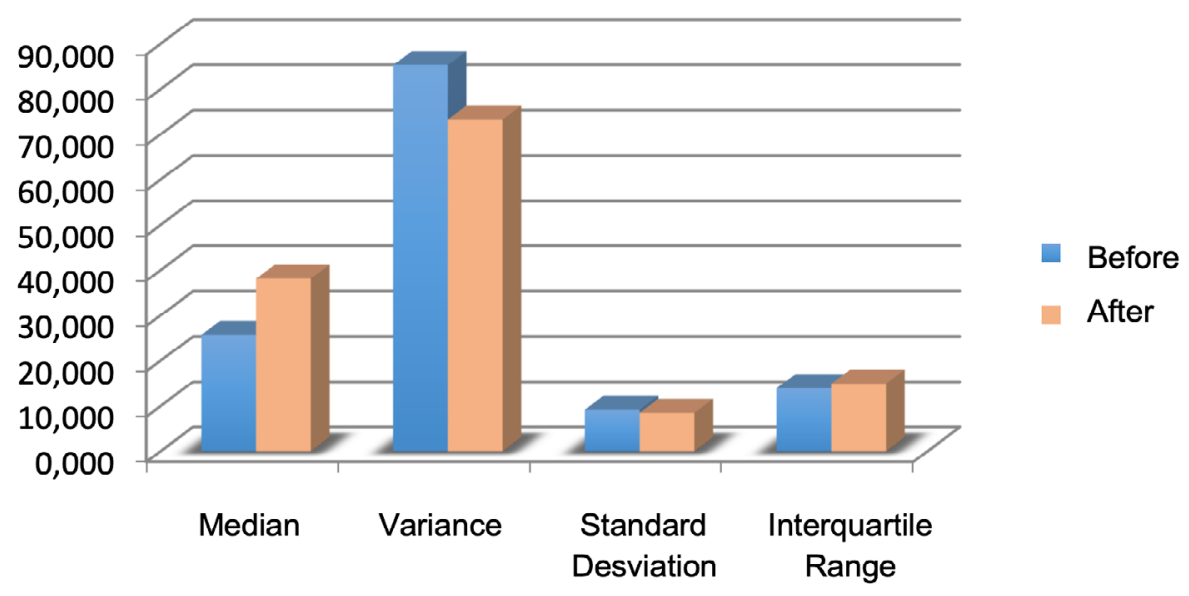

Figure 4. Comparison of the before and after of the ICT Competencies dimension applying the Student's T method. Source: own elaboration.

Table 4. Comparison of the before and after of the Social Competences dimension applying the Student's T method.

\begin{tabular}{|c|c|c|c|c|}
\cline { 2 - 5 } \multicolumn{1}{c|}{} & Median & Variance & Standard Deviation & Interquartile Range \\
\hline Before & 29,09 & 48,797 & 6,986 & 12 \\
\hline After & 37,06 & 39,867 & 6,314 & 12 \\
\hline
\end{tabular}

Source: own elaboration.

Table 5. Comparison of the before and after of the Methodological Strategies dimension applying the Student's $t$ method.

\begin{tabular}{|c|c|c|c|c|}
\cline { 2 - 5 } \multicolumn{1}{c|}{} & Median & Variance & Standard Deviation & Interquartile Range \\
\hline Before & 25,59 & 44,184 & 6,647 & 8 \\
\hline After & 32,34 & 45,072 & 6,714 & 8 \\
\hline
\end{tabular}

Source: own elaboration. 


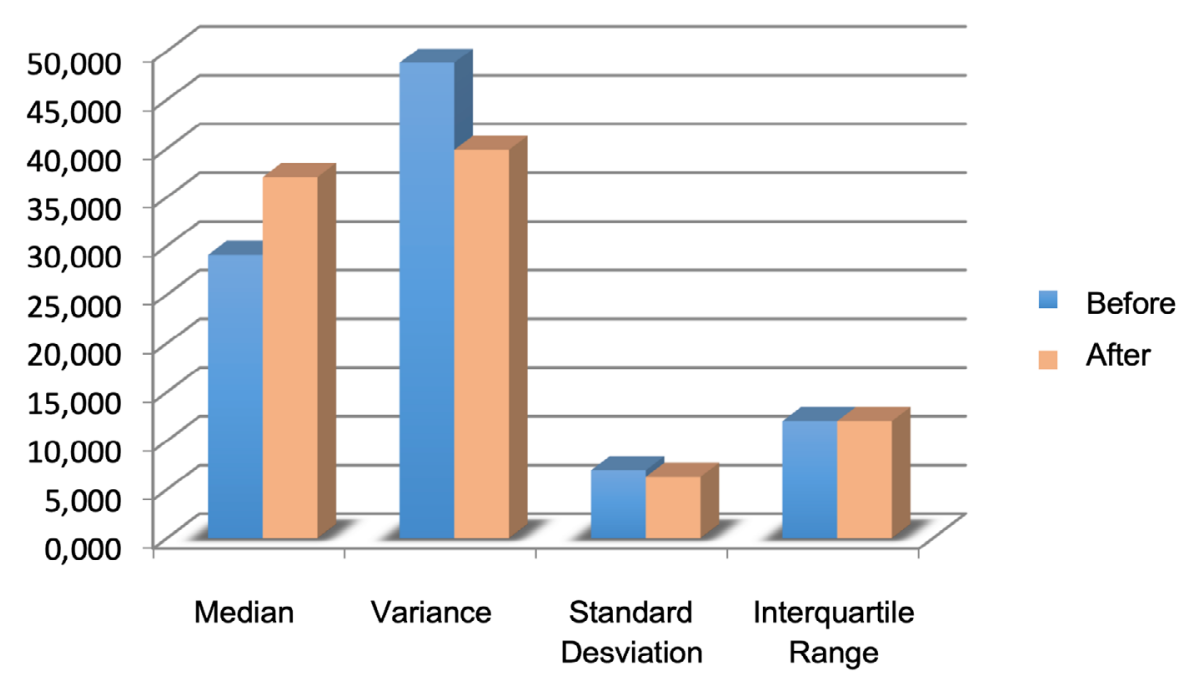

Figure 5. Comparison of the before and after of the Social Competences dimension using Student's T method. Source: own elaboration.

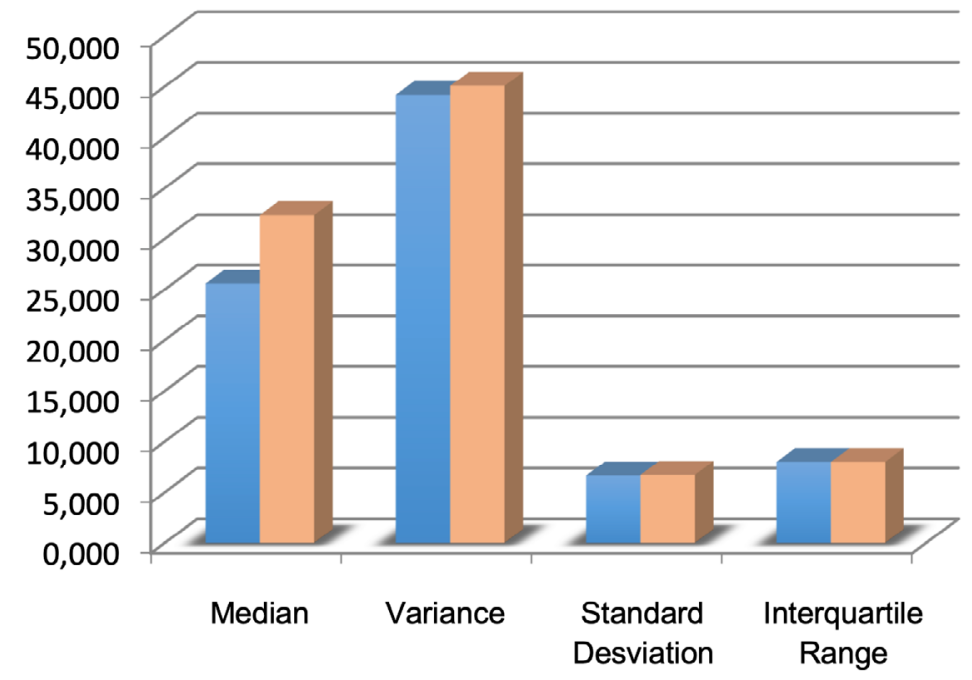

- Before

- After

Figure 6. Comparison of the before and after of the Methodological Strategies dimension applying the Student's $t$ method. Source: own elaboration. 
On performing the respective analysis, we obtained satisfactory results and a high degree of interest on the part of the teachers in improving their competencies.

\section{CONCLUSIONS}

- Based on the research developed on the use of the virtual teaching campus and its influence on the competencies of university teachers, we conclude the following:

- With 95\% confidence, the results demonstrate that there is a high influence $(p=0.000$ and $\alpha=0.05)$.

- It was demonstrated that the use of the Virtual Teaching Campus has a highly significant influence on the level of ICT competencies of teachers, who improved their skills in the management of technological tools.

- The means used by teachers to communicate more with their students increased.

- The teachers improved their methodological strategies by technological advances and current demands, with which the university complies with providing a quality education service.

\section{RECOMMENDATIONS}

It is recommended that teachers be encouraged to use technological tools and new methodological strategies that support virtual teaching through continuous training, since this allows them to have alternatives in the development of the teaching-learning process, communication with their students will be more effective and timelier, and teachers will improve their skills. In addition, it is recommended that the evaluation of technological competencies be included in hiring and appointing teachers. 


\section{REFERENCES}

Alcívar, C. (2019). El uso de las TIC en el proceso de enseñanza- aprendizaje de los docentes en las Universidades del Ecuador. Revista de espacios, 40(2). https://www.revistaespacios.com/a19v40n02/ a19v40n02p27.pdf

Barcia, E., Macías, E., \& Castillo, A. (2017). Desarrollo de las TIC en las universidades. Dominio de las Ciencias, 1(3). https://dominiodelasciencias.com/ojs/index.php/es/article/view/459

Bisquerra, R. (2017). Competencia Social. http:/ /www.rafaelbisquerra.com/es/competencias-emocionales/competencia-social.html

Castro, G. (2019). Formación docente para la implementación de la plataforma virtual moodle como recurso didáctico en educación básica secundaria. Universidad Pedagógica y Tecnológica de Colombia.

Coronado, M. (n.d.). Competencias sociales y convivencia. https://books.google.com.pe/books?id=ZFf9BxV1INkC\&pg =PA133\&lpg=PA133\&dq $=$ competencias + sociales\&source $=$ bl\&ots $=-$ FEWO505Jf\&sig=EJHRneGtb2okOi9HUmIw4Kr50J0\&hl=es-419\&sa=X\&ved=0ahUKEwiWyO6d34fVAhVG4yYKHU7aBhw4ChDoAQgxMAM\#v=onepage\&q=competencias $\% 20$ sociales $\& \mathrm{f}=$ false

Flores, J. (2005). Las plataformas e-Learning como aplicación práctica y metodológica para la enseñanza/aprendizaje del periodismo. http://eprints.ucm.es/6171/1/Ponenciajflores-elearning-vbiena-2005.pdf

Granda, L., Espinoza, E., \& Mayon, S. (2019). Las TIC como herramientas didácticas del proceso de enseñanza-aprendizaje. Revista Conrado, 15(66). https://conrado.ucf.edu.cu/index.php/conrado/article/view/886 


\section{Gutiérrez-Hinestroza, M., Silva-Sánchez, M., Iturralde-Kure, S., \& Mederos-Machado, M.}

G. (2019). Competencias profesionales del docente universitario desde una perspectiva integral. Killkana sociales: Revista de Investigación Científica, 3(1), 1-14. https://dialnet.unirioja.es/servlet/articulo? codigo $=7019215$

Hernández, R. M., Orrego, R., \& Quiñones, S. (2018). Nuevas formas de aprender: La formación docente frente al uso de las TIC. Propósitos y Representaciones, 6(2). http:/ /www.scielo.org.pe/scielo. php?script=sci_abstract\&pid=S2307-79992018000200014\&lng=es\&nrm=iso

Lion, G. (2012). Desarrollo de competencias digitales para portales de la región. http://www.relpe.org/wp-content/uploads/2013/04/09-Desarrollo-de-Competencias-Digitales-para-Portales-de-la-Regi\%C3\%B3n.pdf

Molinero, M., \& Chávez, U. (2019). Herramientas tecnológicas en el proceso de enseñanza aprendizaje en estudiantes de educación superior. Revista Iberoamericana para la investigación y el desarrollo educativo, 10(19). http://www.scielo.org.mx/scielo.php?script=sci_arttext\&pi$\mathrm{d}=\mathrm{S} 2007-74672019000200005$

Perrenoud, P. (2004). Diez nuevas competencias para enseñar. (1. ${ }^{\mathrm{a}}$ ed.). Editorial Grao.

Picón, M. (2020). ¿Es posible la enseñanza virtual? Foro educacional, 1(34), 11-34. https://dialnet.unirioja.es/servlet/articulo? codigo $=7516997$

Ramírez, A. (2020). La valoración de un curso virtual: Caso propuesta de un modelo de indicadores para la valorar un curso a docentes, por medio de una plataforma virtual de aprendizaje. Revista digital de divulgación e investigación turística, 10(10), 1-17.

Vidal, M. (2004). Uso y evaluación de la Plataforma de enseñanza y aprendizaje virtual "Blackboard". http:// docs. moodle.org/en/About_Moodle 
